six months. Twelve patients (group 4) showed a positive response to their own spray, with a further significant response to the standard aerosol, and are therefore assumed not to be obtaining the maximum benefit from their normal therapy. Of these, nine were using their spray incorrectly ; three were using it correctly, but again one of these was using a proprietary nebulizer and solution which he had had for five months. The remaining 18 patients (group 3) could be shown to respond to their own spray with no further response to the standard. Eleven of these were using their spray correctly. Excluding all those subjects shown not to respond significantly to bronchodilators, a comparison has been made between those who used pressurized aerosols and those who used rubber-bulb nebulizers (Table II). Of the 11 patients using a pressurized aerosol correctly, only two did not gain maximum response. Of the 14 using such an aerosol incorrectly, no fewer than 11 failed to gain maximum response.

TABLE II

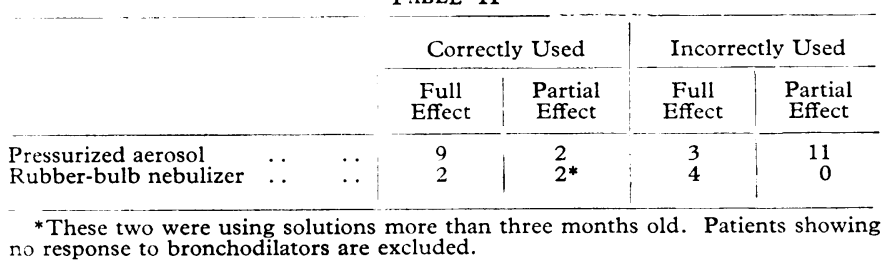

Age of Nebulizer Solutions.-Of the 12 patients using nebulizers, four were refilling them with solutions in their possession for more than three months; two of these had gained only partial benefit, although they used them correctly.

Original Prescriber.-The original prescription for the spray was given by the general practitioner in 16 cases, by this hospital in 27 , and by other hospitals in three.

Previous Instruction. - Thirty-three patients had previously been instructed in the correct use of their spray. Nine had been given written instructions. Only four had received neither form of direction.

\section{Discussion}

Chronic bronchitis is the second most important cause of morbidity in this country. Many bronchitics require bronchodilator therapy, given either by inhalation or orally. Inhalants are often prescribed alone, or in addition to oral bronchodilators, because they act faster and are at first sight easy to use. Pressurized containers are the most convenient and deliver a measured dose. It is clear that correct use of such an apparatus is essential ; but in this study it was not often attained.

In this clinic a reasonable attempt had been made to instruct each patient in the use of his spray on one occasion, a routine probably representative of that used in most busy out-patient departments. This survey shows that one initial period of instruction is inadequate. Centres which customarily take more care in instruction would expect to produce more effective therapy.

Of the eight subjects using rubber-bulb nebulizers, four used them incorrectly, but all used them for over one minute at each application. Only two failed to gain maximum bronchodilatation; both of these were using solutions five or more months old. A solution of isoprenaline 1\% B.P.C., in the usual brown glass bottle, was placed on a laboratory shelf not in direct sunlight. It became discoloured in 10 days.

\section{Summary}

A detailed inquiry was made into the use and effect of bronchodilators in 46 patients routinely attending a chest department.

Of these, 13 showed no response to bronchodilators under criteria defined above.

Eighteen gained full benefit from their spray as normally used.

The remaining 15 , though able to respond to bronchodilators, were gaining either a partial response or none at all. Eleven of these were using their spray incorrectly, and two were using solutions five or more months old.

I wish to thank Dr. D. S. Cadman 'for permission to study his patients, Dr. D. G. Wraith for the loan of the D30 aerosol generator, and Dr. W. W. Holland for his help and advice throughout.

\section{REFERENCES}

Collins, M. M., McDermott, M., and McDermott, T. J. (1965). f. Physiol. (Lond.). In press.

Dautrebande, L., and Lovejoy, F. W. (1961). Arch. int. Pharmacodyn., 131, 230 .

Wright, B. M., and McKerrow, C. B. (1959). Brii. med. F., 2, 1041.

\title{
A Eunuch Takes the Gout
}

\author{
A. J. S. MCFADZEAN, * O.B.E., M.D., F.R.C.P., F.A.C.P
}

Brit. med. F., 1965, 1, 1038-1039

Eunuchs do not take the gout, nor become bald.Aphorism of Hippocrates.

Galen, in his commentary on the above aphorism, claims that it did not hold for the eunuchs of Imperial Rome. In an admirable presentation of the long and memorable history of gout Copeman (1964) paraphrases the commentary thus ". . . whilst agreeing that this [the aphorism] was basically true, [Galen] said that in his time, however, such was their indolence and viciousness that they [eunuchs] occasionally did so." On the other hand, the paraphrase by Adams (1849) of the same commentary reads, "while it was true in Hippocrates'

* University Department of Medicine, Queen Mary Hospital, Hong Kong. time that eunuchs did not take the gout in his [Galen's] time they were exposed to the disease because of their indolence and effeminacy." In each of two versions of the commentary available to me there are two sentences which, if divorced from their context, clearly convey that eunuchs suffered from the gout. "Ob hanc igitur causam etiam eunuchi podagra corripiuntur, quamuis nullum habeat usum venereorum. Talis enim est eorum desidia, ingluuies, ebrietas, ut etiam sine venereis podagra corripi possint" (1550). “ $\mathrm{Ob}$ has igitur causas eunuchi etiam podagrae doloribus cruciantur, etiamsi quam maxime sibi a venere temperent. Tanta enim eorum est desidia, tam inexplebilis edacitas, tanta crapula, ut etiam sine coitu, podagra corripi possint" (1633). However, the paraphrase by Adams (1849), provided he is allowed the delicacy of 
" effeminacy," seems the more accurate, for the commentary as a whole strongly suggests an indulgence in speculation to which Galen was prone. There is no evidence that Galen had seen a eunuch with the gout. But, independent of whether the commentary was based on observation or on speculation, testimony to its accuracy in the main is borne by this report of an encounter in the twentieth century with a eunuch who had taken the gout.

\section{Case Report}

The patient, aged 70, was an irascible northern Chinese from "near Tientsin," who appeared to be of great age yet, paradoxically, conveyed also an impression of youthfulness. This was due to a strange waxen appearance of the skin of the face, which, viewed from a distance, seemed unlined, whereas closer scrutiny revealed a myriad of fine wrinkles. The history was difficult to obtain, and questions were answered with reluctance in a querulous voice no higher-pitched than that commonly encountered in Chinese. Repeatedly he upbraided his friend for having brought him to see the "prying, foreign devil," from whom not even his ancestors were safe.

For some 35 years he had suffered from intermittent acute attacks of severe joint pain. The metatarsophalangeal joint of the right great toe was first attacked, and his description of both the attack and the appearance of the foot was consistent with gout. With the passage of time other joints were affected. As the disease advanced the attacks became more frequent, there were no longer intervals of freedom from pain, and the feet and hands became deformed. He made it abundantly plain that the joints were being well enough looked after by a practitioner of traditional Chinese medicine; he was seeking relief from attacks of intolerable pain associated with deafness in one or both ears. There was a history of gout in his father's family.

On being questioned concerning urinary symptoms he evinced both anger and distress, eventually replying that ever since his youth there had been intermittent obstruction to urinary flow relieved by the passage of bougies. This history of a stricture brought recognition of the significance of the waxen skin and strange appearance. He admitted being a eunuch, said that the operation was performed when he was about 12 years old, and thereafter refused to discuss the matter. $\mathrm{He}$ insisted that this was the first time he had seen a "Western doctor," and it was evident that it was going to be the last. It may be assumed, therefore, that he had never received androgens.

$\mathrm{He}$ was even more difficult while being examined. Both feet and hands were grossly deformed by ulcerative tophaceous gout, and a scraping of the "chalk" was shown to contain needle-like crystals, and to give a positive murexide test. There were tophi on both ears. The right external auditory meatus was obstructed by an acute inflammatory reaction which extended to involve the concha, tragus, and antitragus.

The genitalia had been completely removed, and the urethra was found with difficulty in a mass of keloids. At this juncture the patient refused to be examined further, refused venesection, and refused, angrily, a request to photograph him.

\section{Discussion}

There is no doubt that the patient, a eunuch, was suffering from gout, which is common among the Chinese in Hong Kong. This confirms Galen's comment that eunuchs can be afflicted by gout ; but here support for his commentary ends. The eunuch described, according to his friend, had lived a hermit-like existence in near penury for some 50 years, a life far removed from the high and evil living which Galen considered responsible for the appearance of the disease among the eunuchs of Rome.

So far as the patient's gout is concerned, the acute involvement of the ear is of interest. The older generations of Chinese clear wax from the external auditory meati with a little spoon usually made of ivory, bone, whale-bone, or silver. Exceedingly painful attacks of acute "otitis externa" with an inflammatory reaction involving the auricle occur in sufferers from gout who do this. The attacks respond rapidly to colchicine, and no longer occur after stopping the practice. The patient reported here used an ivory spoon, but it is doubtful if he accepted the advice to throw it away.

In Imperial China only the imperial household and the households of the eight hereditary princes were allowed by law to have eunuchs. For many centuries Ho-chien-fu, a city 100 miles $(160 \mathrm{~km}$.) south of Tientsin, provided the majority of these eunuchs (Wong and Wu, 1933). The patient must either have seen service or was being trained for service in one of these households, for the operation was performed five years before the overthrow of the Ch'ing Dynasty. He admitted coming from "near Tientsin," and, although he refused to confirm this, it is probable that his native city was Ho-chien-fu.

Wong and $\mathrm{Wu}$ (1933) describe the operation as it was performed in Imperial China, and probably that performed in this instance. After the application of tight bandages round the "hypogastric" and inguinal regions, and the bathing of the penis and scrotum with a hot decoction of pepper pods, " all the parts are swiftly swept away by one stroke of a sickleshaped knife, a pewter plug is inserted into the urethra, the wound is covered with paper soaked in cold water and firmly bandaged." H. H. Loucks (personal communication, 1964), while professor of surgery in Peking, found that the operation was commonly followed by a stricture of the residual urethra, a complication which had occurred in the present instance.

\section{REFERENCES}

Adams, F. (1849). The Genuine Works of Hippocrates. New Sydenham Society, London

Copeman, W. S. C. (1964). A Short History of the Gout. University of California Press, Berkeley, Calif.

Galen (1550). Opera omnia, tom. 6: Galeni extra ordinem classium libri. Venice.

Venice. A. Foesii et G. Plantii. Ed. nova ab A. Toll. Lugduni Batavorum (Leyden), ex off. J. Maire.

Wong, K. C., and Wu, L-t. (1933). History of Chinese Medicine. Tientsin Press, Tientsin. 